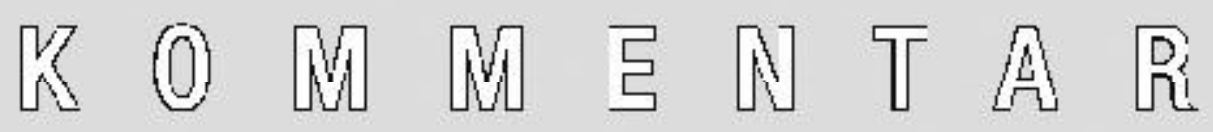

af Bjarne Andersson

\title{
Produceres den offentlige mening i medierne?
}

Steen Vallentin forsøger i forrige nummer af Dansk Sociologi $(2005, \mathrm{nr} .3)$ at "klargøre, hvordan den offentlige mening kan forstås og gøres empirisk iagttagelig og analysérbar ud fra en konstruktivistisk sociologisk forståelsesramme“ (s. 25).

Hans analytiske interesse samler sig om tre dimensioner ved "den offentlige mening": måling, mobilisering og medier. Steen Vallentins analytiske tilgang er (på trods af at den ikke falder sammen med min) legitim for at udbygge den sociologiske viden om dette flygtige og svært håndterbare begreb. Ikke desto mindre mener jeg, at Steen Vallentin vælger en del teoretiske smutveje, der minimerer udbyttet af hans analyse. Lad mig give nogle eksempler.

Steen Vallentin medgiver (s. 33), at man kan betragte meningsmålinger som udtryk for den offentlige mening, men at der vel at mærke er tale om atomistiske meninger indsamlet $\mathrm{i}$ kunstige, iscenesatte, stemmeboksligninde situationer. Vi må tro at det, der kommer ud af målingerne, er aggregerede individuelle meninger, og at de kun så at sige bliver offentlige ved at blive publiceret og offentliggjort.

Her er det teoretiske gærde blevet lovlig lavt. De meninger, der samles ind (jeg har før gjort opmærksom på at "mening" på dansk har nogle uheldige konnotationer, men jeg vil i denne sammenhæng holde mig til Steen Vallentins terminologi), er godt nok individuelle, for så vidt det er enkeltindivider, der svarer på spørgsmålene, men Steen Vallentin får ikke i sin teoretiske optik mulighed for at gå dybere. Han får ikke mulighed for at overveje, at alle de individuelle meninger ikke dannes "on the fly" $\mathrm{i}$ svarsituationen, men er indlejret i det enkelte individ på basis af kommunikation og handlinger med familie, venner, arbejdskolleger osv. Det, Steen Vallentin (og for så vidt de kritikere han støtter sig til f.eks. Blumer og Bourdieu) udgrænser af analysen, er netop en refleksion af hvor "den offentlige mening" dannes - i det enkelte menneskes liv eller i nyhedsmedierne.

Steen Vallentin vil gerne hæve analysen til et anden ordens niveau "hvor den offentlige mening fremstår som en form for symbolsk repræsentation ... en diskursiv konstruktion, der gøres gældende i en offentlig sfære i et funktionelt differentieret samfund" (s. 36). Her træder den luhmannske synsvinkel i forgrunden ved at bortanalysere komplekset holdning/handling til fordel for en ren diskur- 
siv synsvinkel. Det, Steen Vallentin får ud af denne strategi, er endnu et "fladt" billede af den individuelle konstruktion af den offentlige mening. Vi må tro, at meningsmålinger altid iscenesættes af aktører, der har en anden dagsorden end de personer, der svarer på spørgsmålene, men er det nødvendigvis korrekt?

Vi har jo heldigvis en tilbagevendende stor spørgeskemaundersøgelse, vi kan falde tilbage på: meningsmålingerne op til folketingsvalgene. Her fortæller vi i meget skematisk form, om vi går ind for bibeholdelse af efterlønsordningen, fremmede, flere penge til forskning osv. osv. Det er den ultimativt aggregerede meningsmåling (værdikompleks-undersøgelse ville jeg kalde den), men den kendsgerning, at de kommercielle medier samt public service institutionerne prøver at "sælge" vores egne meninger tilbage til os for henholdsvis at true eller lokke os til at handle på en bestemt måde ved selve valget, er ikke ensbetydende med at den offentlige mening kun sociologisk set eksisterer på det diskursive plan. Dansk Folkepartis fremgang ved de seneste folketingsvalg er et relativt klart udtryk for, at den politiske diskurs, som Steen Vallentin fokuserer på, ikke kan rumme de individuelle og kollektive meninger, som vi i visse sammenhænge må opfatte som protester mod den diskurs, vi kan kalde "den politisk korrekte mening", uanset hvor store anstrengelser de forskellige medier gør sig.

Nogle samfundsforskere slår til lyd for, at den offentlige mening (aggregerede holdninger eller værdi-elementer) afspejler en "seriel atomisering", der ikke kan bruges som pejlemærke i situationer af mere kompleks karakter end f.eks. en "løsning-på-et-givet-problem". De mener, at det eneste demokratiske alternativ til atomiseringens aggregering er en form for autoriseret uddelegering, hvor repræsentanter udtaler sig eller vælger løsninger på vegne af en større samling individer, der har oparbejdet et niveau af fælles viden/erfaring/kreativitet - en "forening"; altså en velkendt (social)demokratisk praksis, som hjælper underklassen fri af det liberale krav om individuelle ansvarlige strategier for deres liv og overlevelse. Vurderet i denne sammenhæng er det tydeligt, at Steen Vallentin's sociologiske analyse meget nemt risikerer at blive spændt for konfliktende politiske interesser i forsøget på at underholde os med, hvordan vi er/mener/ tænker - i hvert fald hvad naboen mener om os.

Det Steen Vallentin formulerer som sit kritikfokus, nemlig at den offentlige mening "ikke er en kausal, udefra kommende kraft, der uden videre sætter sig igennem og bemægtiger sig beslutningsprocesser" (s. 41), er vel næppe en forestilling ret mange sociologer ville gøre til deres egen. Hvordan vi kan komplementere Steen Vallentin's analyse uden at trække den diskursteoretiske dimension helt ud er et mere alvorligt spørgsmål.

Konkret ville det f.eks. fordre, at der politisk blev stillet forslag om, at alle danskere skulle kunne deltage i et demokratispil, hvor odds for uden- og indenrigspolitiske udviklingsplaner skulle dannes. Hvad er odds for terrorhandlinger i Danmark i 2006 og hvor vil de foregå? Vil der komme nye, dødelige sygdomsepidemier til landet? Hvilke sygdomme skal behandles fremover (dvs. en prioriteret liste over sygdomme med tilhørende finansieringsforslag)? Mange kon- 
krete undersøgelser peger på, at det ville være en rigtig god idé. Vi ville se ekspertgrupper og interesseorganisationer på banen, men kun i det omfang deres medlemmer var aktive nok og tilmeldte sig demokratispillet. De danskere, der har det bedst med at ligge henslængt i deres sofa, kunne via deres bærbare deltage $\mathrm{i}$ demokratispillet (og begrebet sofavælger ville få nyt liv). Dette demokratispil leder tankerne hen på oldtidens græske traditioner, hvor folket (godt nok kun den frie del af folket) mødtes, stemte ved håndsoprækning, og så var beslutningerne truffet. Men er en vis portion sagsrelateret viden ikke uomgængelig nødvendig, hvis der skal komme levedygtige beslutninger ud af det. Med andre ord: er der ikke mere overlevelse og demokratisk væksti en vifte af ekspertpaneler, der kan give sandsynlige svar på de samfundsmæssigt vigtige spørgsmål? Nej, det ser ikke sådan ud. Eksperter har en tilskyndelse til at basere deres svar og skøn på allerede kanoniseret viden. For eksempel blev de sociologiske eksperter populært sagt taget med bukserne nede, da Sovjetunionen og Østeuropa kollapsede i 1998. De økonomiske eksperter var ikke forberedt på, at IT-boblen bristede i begyndelsen af 2001.

Det er klart, at et sådant demokratispil - snarere end at blive hyldet som konkretiseringen af den offentlige mening som diskursivt fænomen - ville blive mødt af protester fra magthavere, kapitalister, levebrødspolitikere og eksperter, men al begyndelse er som bekendt svær, og begyndelsen ligger bl.a.i den måde vi omgås vores børn, hinanden og vores politiske modstandere på, mens vi i fællesskab stille og roligt producerer individuelle elementer af "den offentlige mening".

Bjarne Andersson

E-mail: basso@ruc.dk 